\title{
Effects of S-Abscisic Acid and (+)-8' - Acetylene Abscisic Acid on Fruit Set and Stomatal Conductance in Apple
}

\author{
Steven J. McArtney ${ }^{1,2}$ \\ Department of Horticultural Science, North Carolina State University, \\ Mountain Horticultural Crops Research and Extension Center, 455 Research \\ Drive, Mills River, NC 28759
}

\section{Suzanne R. Abrams \\ Department of Chemistry, University of Saskatchewan, Saskatoon, SK S7N 5C7, Canada}

\author{
Derek D. Woolard and Peter D. Petracek \\ Valent BioSciences Corporation, 6131 Oakwood Road, Long Grove, IL \\ 60047
}

Additional index words. ABA catabolism, carbohydrate stress, chemical fruit thinning, fruit abscission, Malus $\times$ domestica Borkh., S-ABA

\begin{abstract}
Fruit set of apple can be reduced by cloudy weather, short-term shade treatments, or application of photosynthetic inhibitors when the young fruit are $\approx 8$ to $15 \mathbf{~ m m}$ in diameter, indicating that fruit are sensitive to a transient carbohydrate stress during this period. We investigated the potential for $\mathrm{S}$-abscisic acid (ABA) and an ABA analog $\left[(+)-8^{\prime}\right.$-acetylene $\left.\mathrm{ABA}\right]$ to chemically thin apple fruit by causing a stomatal limitation of photosynthesis. Stomatal conductance $\left(g_{S}\right)$ of 'Imperial Gala'/M.7 was reduced by $60 \% 3 \mathrm{~h}$ after application of $250 \mathrm{mg} \cdot \mathrm{L}^{-1} \mathrm{ABA}$ or $25 \mathrm{mg} \cdot \mathrm{L}^{-1}(+)-8^{\prime}$-acetylene ABA. Stomatal conductance began to recover 4 days after application but did not return to control levels until 19 days after treatment. Application of $250 \mathrm{mg} \cdot \mathrm{L}^{-1} \mathrm{ABA}$ combined with $100 \mathrm{mg} \cdot \mathrm{L}^{-1}$ 6-benzyladenine $(6-B A)$ when mean fruit diameter was $\approx 10 \mathrm{~mm}$ reduced fruit set of 'Gala'/M.7 but not 'Pink Lady' ${ }^{\text {TM'} / M .7 ~ o r ~ ' M o r g a n s p u r ~ D e l i c i o u s ' / M M .111 . ~}$ Fruit set of 'Pink Lady ${ }^{\mathrm{TM}}$ '/M.7 was reduced by application of $20 \mathrm{mg} \cdot \mathrm{L}^{-1}(+)-8^{\prime}$-acetylene ABA $+100 \mathrm{mg} \cdot \mathrm{L}^{-1}$ 6-BA at full bloom or $10 \mathrm{mg} \cdot \mathrm{L}^{-1}(+)-8^{\prime}$-acetylene ABA $+100 \mathrm{mg} \cdot \mathrm{L}^{-1}$ 6-BA at the 10-mm fruit diameter stage. Fruit set of 'Morganspur Delicious'/MM.111 was reduced by application of $25 \mathrm{mg} \cdot \mathrm{L}^{-1}(+)-8^{\prime}$-acetylene $\mathrm{ABA}$, either alone or in combination with $75 \mathrm{mg} \cdot \mathrm{L}^{-1}$ 6-BA, at the 10-mm fruit diameter stage. $\mathrm{ABA}$ and $(+)-8^{\prime}$-acetylene $\mathrm{ABA}$ triggered leaf abscission at rates above $250 \mathrm{mg} \cdot \mathrm{L}^{-1}$ and $25 \mathrm{mg} \cdot \mathrm{L}^{-1}$, respectively. Fruit set and $g_{S}$ data from the present studies indicate the biological activity of $(+)-8^{\prime}$-acetylene $A B A$ is 10 -fold higher than $\mathrm{ABA}$. These results suggest that $\mathrm{ABA}$ and $(+)-\mathbf{8}^{\prime}$-acetylene $\mathrm{ABA}$ reduced fruit set by causing a stomatal limitation in photosynthesis that resulted in a transient carbohydrate stress. Thinning responses to $\mathrm{ABA}$ and $(+)-8^{\prime}$-acetylene $\mathrm{ABA}$ at the concentrations used in these experiments were reduced compared with standard concentrations of currently available chemical thinning agents. However, increasing the concentration of $\mathrm{ABA}$ or $(+)-8^{\prime}$-acetylene $\mathrm{ABA}$ to levels that would achieve comparable thinning are also likely to result in unacceptable leaf abscission.
\end{abstract}

Developing apple (Malus $\times$ domestica) fruit represent a relatively small carbohydrate sink between budbreak and bloom. Fruit are insensitive to an environmentally induced carbohydrate stress during this period and

\footnotetext{
Received for publication 16 Dec. 2013. Accepted for publication $24 \mathrm{Feb} .2014$.

Technical assistance of J.D. Obermiller is gratefully acknowledged.

Mention of a trademark, proprietary product, or vendor in this publication does not constitute a guarantee or warranty of the product and does not imply its approval to the exclusion of other products or vendors that may also be suitable.

${ }^{1}$ Southeast Apple Specialist.

${ }^{2}$ To whom reprint requests should be addressed; e-mail steve_mcartney@ncsu.edu.
}

the carbohydrates required for growth are derived from reserves (Lakso, 2011). However, as the supply of carbohydrates from reserves is depleted and the fertilized fruit begin to grow rapidly, they become increasingly dependent on current assimilates. Shoot growth has priority over fruit growth for carbohydrate partitioning when light levels during the first $40 \mathrm{~d}$ after bloom are limiting (Bepete and Lakso, 1998). The negative effect of postbloom shade treatments (Byers et al., 1985, 1990, 1991; McArtney et al., 2004; Zibordi et al., 2009) or photosynthetic inhibitors (Basak, 2011; Byers et al., 1985, 1990; Clever, 2007; Deckers et al., 2010; Dorigoni and Lexxer, 2007; Lafer, 2010; McArtney and Obermiller, 2012a, 2012b) on fruit set provides evidence that a transient limitation in carbohydrate supply can act as a strong trigger for abscission of apple fruit.

Exogenously applied ABA during early fruit development stimulates fruit abscission in apples (Edgerton, 1971; Greene et al., 2011), European pears (Pyrus communis) (Greene, 2012), and cherries (Prunus avium) (Zucconi et al., 1969) at concentrations ranging from 150 to $1000 \mathrm{mg} \cdot \mathrm{L}^{-1}$. The exact mode of action of ABA in apple fruitlet abscission is unknown but is probably related to a combination of ethylene induction (Edgerton, 1971) or the creation of a transient carbohydrate stress resulting from stomatal limitation of photosynthesis. Lakso (1979) reported a close linear correlation between $g_{\mathrm{S}}$ and net photosynthesis in apple trees growing under a wide range of water stress conditions, indicating that photosynthesis is primarily limited by $g_{\mathrm{S}}$ under nonlimiting light and temperature conditions. More recently, Massonnet et al. (2007) reported that the relationship between $g_{\mathrm{S}}$ and photosynthesis was different in 'Braeburn' and 'Fuji' apples, although net $\mathrm{CO}_{2}$ assimilation rate in both cultivars was positively related to $g_{\mathrm{S}}$.

ABA is rapidly catabolized in plants, principally through oxidation of the $8^{\prime}$-methyl group to $8^{\prime}$-hydroxy $\mathrm{ABA}$, which is itself further cyclized to biologically inactive phasic acid (Balsevich et al., 1994). This reaction is catalyzed by ABA $8^{\prime}$ hydroxylase, a cytochrome P450 monoxygenase (Krochko et al., 1998). It has been suggested that ABA levels in plants could be regulated by controlling ABA catabolizing enzymes, resulting in increased stress tolerance or plants with altered seed germination and composition traits (Rose et al., 1997). This possibility was recently demonstrated by Kondo et al. (2012) who reported prompt stomatal closure and increased dehydration tolerance in apple seedlings after treatment with a specific inhibitor of ABA 8' hydroxylase [Abscinazole-F1, an analog of uniconazole with no growth retardant activity (Todoroki et al., 2009)]. An analog of ABA, (+)-8' -acetylene ABA (Fig. 1), was shown to weakly inhibit ABA $8^{\prime}$-hydroxylase (Rose et al., 1997). (+)-8' -acetylene ABA is a poor substrate for ABA 8 ' hydroxylase, resulting in greater persistence and stronger hormonal activity than ABA itself (Cutler et al., 2000). The objectives of the present study were to confirm the thinning activity of $\mathrm{ABA}$ and to compare the effects of ABA and $(+)-8^{\prime}$-acetylene $\mathrm{ABA}$ on fruit set and $g_{\mathrm{S}}$ in apple.

\section{Materials and Methods}

All trees used in this series of experiments were growing at the North Carolina State University Mountain Horticultural Crops Research and Extension Center in Mills River, $\mathrm{NC}$, and exhibited uniform heavy bloom in the year of treatment. The trees were in mature orchards planted at $6.0 \mathrm{~m}$ between rows and $3.0 \mathrm{~m}$ between trees in the row (556 trees/ha), trained to a central leader, and managed according to accepted commercial practices as described in the Integrated Orchard Management Guide for Commercial 
Apples in the Southeast (Anon., 2013). An industry standard thinning spray of 75 to 100 $\mathrm{mg} \cdot \mathrm{L}^{-1}$ 6-BA plus $600 \mathrm{mg} \cdot \mathrm{L}^{-1}$ carbaryl was included in all thinning experiments.

'Imperial Gala'/M.7-2010. Forty-two uniform trees were selected at bloom from a block of 15-year-old 'Imperial Gala'/'Malling 7' (M.7) trees. The following seven treatments were assigned to fully guarded single-tree plots in a randomized complete block design experiment with six replications: 1) an untreated control; 2) a standard chemical thinning treatment of $100 \mathrm{mg} \cdot \mathrm{L}^{-1}$ 6-BA (MaxCel; Valent BioSciences, Libertyville, IL) plus $600 \mathrm{mg} \cdot \mathrm{L}^{-1}$ carbaryl (Carbaryl 4L; Drexel Chemical Co., Memphis, TN); 3) $100 \mathrm{mg} \cdot \mathrm{L}^{-1}$ 6-BA plus $250 \mathrm{mg} \cdot \mathrm{L}^{-1} \mathrm{ABA}$ (Valent BioSciences); 4) $100 \mathrm{mg} \cdot \mathrm{L}^{-1}$ 6-BA plus $500 \mathrm{mg} \cdot \mathrm{L}^{-1} \mathrm{ABA} ; 5$ ) $100 \mathrm{mg} \cdot \mathrm{L}^{-1}$ 6-BA plus $750 \mathrm{mg} \cdot \mathrm{L}^{-1} \mathrm{ABA}$; 6) $100 \mathrm{mg} \cdot \mathrm{L}^{-1} 6$-BA plus $7.5 \mathrm{mg} \cdot \mathrm{L}^{-1}$ naphthalene acetic acid (NAA, Fruitone L; AMVAC Chemical Corp., Los Angeles, CA); and 7) 500 $\mathrm{mg} \cdot \mathrm{L}^{-1}$ ABA plus $7.5 \mathrm{mg} \cdot \mathrm{L}^{-1} \mathrm{NAA}$. Throughout this article, ABA refers to the S-enantiomer of abscisic acid. The treatments were applied with an airblast sprayer calibrated to deliver $1700 \mathrm{~L} \cdot \mathrm{ha}^{-1}$ when the mean diameter of spur fruit was $9.7 \mathrm{~mm}$. No additional surfactants were included with any of the treatments. Three uniform sample limbs were selected on each tree just before bloom and the total number of flower clusters on spurs was counted on each limb. The number of spur fruit remaining on each limb was counted after the completion of fruit drop. Fruit set was calculated as the number of remaining spur fruit per 100 spur clusters. Total fruit number per tree, total fruit weight, and fruit size distribution were measured at harvest.

'Pink Lady ${ }^{\mathrm{TM}}$ '/M.7-2012. A randomized complete block design experiment with five blocks and eight treatments was established in a planting of mature 'Pink Lady ${ }^{\mathrm{TM}}$ '/M.7 apple trees. The treatments included an untreated control, three chemical thinning treatments applied at full bloom, and four thinning treatments applied when the mean fruit diameter was $10 \mathrm{~mm}$. The three chemical thinning treatments applied at full bloom were 1) 100 $\mathrm{mg} \cdot \mathrm{L}^{-1}$ 6-BA plus $250 \mathrm{mg} \cdot \mathrm{L}^{-1} \mathrm{ABA}$; 2) 100 $\mathrm{mg} \cdot \mathrm{L}^{-1} 6$-BA plus $10 \mathrm{mg} \cdot \mathrm{L}^{-1}(+)-8^{\prime}$-acetylene ABA; and 3) $100 \mathrm{mg} \cdot \mathrm{L}^{-1} 6-\mathrm{BA}$ plus $20 \mathrm{mg} \cdot \mathrm{L}^{-1}$ $(+)-8^{\prime}$-acetylene ABA. The four thinning treatments applied at the $10-\mathrm{mm}$ fruit diameter stage

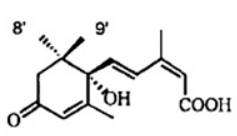

S-Abscisic acid

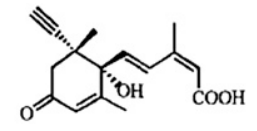

(+)-8'-Acetylene abscisic acid

Fig. 1. Structures of S-abscisic acid (ABA) and (+)-8' -acetylene abscisic acid.

Table 1. Effect of various combinations of S-abscisic acid (ABA), benzyladenine (6-BA), carbaryl, and naphthalene acetic acid (NAA) thinning treatments on fruit set, yield and fruit number per tree, and mean fruit weight of 'Imperial Gala'/M.7 apple. ${ }^{\mathrm{z}}$

\begin{tabular}{lcccc}
\hline & $\begin{array}{c}\text { Fruit set } \\
\text { (fruit/100 clusters) }\end{array}$ & Yield (kg/tree) & Fruit (no./tree) & Mean fruit wt (g) \\
\hline Control & $89 \mathrm{a}$ & $116 \mathrm{a}^{\mathrm{y}}$ & $1087 \mathrm{a}$ & $106 \mathrm{~d}$ \\
6-BA (100) + carbaryl (600) & $34 \mathrm{~d}$ & $78 \mathrm{bc}$ & $592 \mathrm{~d}$ & $133 \mathrm{a}$ \\
6-BA (100) + ABA (250) & $66 \mathrm{~b}$ & $101 \mathrm{ab}$ & $908 \mathrm{ab}$ & $112 \mathrm{~cd}$ \\
6-BA (100) + ABA (500) & $50 \mathrm{c}$ & $86 \mathrm{bc}$ & $722 \mathrm{bcd}$ & $118 \mathrm{bcd}$ \\
6-BA (100) + ABA (750) & $57 \mathrm{bc}$ & $75 \mathrm{bc}$ & $646 \mathrm{~cd}$ & $117 \mathrm{bcd}$ \\
6-BA (100) + NAA (7.5) & $31 \mathrm{~d}$ & $72 \mathrm{c}$ & $559 \mathrm{~d}$ & $129 \mathrm{ab}$ \\
ABA (500) + NAA (7.5) & $62 \mathrm{bc}$ & $101 \mathrm{ab}$ & $812 \mathrm{bc}$ & $123 \mathrm{abc}$ \\
Significance & $* * *$ & $* *$ & $* * *$ & $* *$ \\
\hline
\end{tabular}

zTreatments were applied when the mean fruit diameter was $9.7 \mathrm{~mm}$.

${ }^{y}$ Means within a column followed by different letters are significantly different at $P \leq 0.05$ as determined by Duncan's multiple range test $(\mathrm{n}=5)$.

x**, *** Significant at $P<0.01$ or 0.001 , respectively. were 1) a standard chemical thinning treatment of $100 \mathrm{mg} \cdot \mathrm{L}^{-1} 6$-BA plus $600 \mathrm{mg} \cdot \mathrm{L}^{-1}$ carbaryl; 2) $100 \mathrm{mg} \cdot \mathrm{L}^{-1} 6$-BA plus $250 \mathrm{mg} \cdot \mathrm{L}^{-1} \mathrm{ABA}$; 3 ) $100 \mathrm{mg} \cdot \mathrm{L}^{-1}$ 6-BA plus $10 \mathrm{mg} \cdot \mathrm{L}^{-1}(+)-8^{\prime}-$ acetylene $\mathrm{ABA}$; and 4) $100 \mathrm{mg} \cdot \mathrm{L}^{-1}$ 6-BA plus $20 \mathrm{mg} \cdot \mathrm{L}^{-1}(+)-8^{\prime}$-acetylene ABA. The spray treatments were applied to fully guarded singletree plots with an airblast sprayer calibrated to deliver $1420 \mathrm{~L} \cdot \mathrm{ha}^{-1}$. No additional surfactants were included with any of the treatments. Fruit set was measured as in the previous experiment. Trees in this study did not receive any additional hand-thinning. Total fruit number and weight per tree were recorded at harvest and mean fruit weight was calculated from the data.

'Morganspur Delicious'/MM.111-2013. Thirty-five uniform trees were selected at bloom from a block of 'Morganspur Delicious'/'Malling Merton 111' (MM.111) trees. The following seven treatments were assigned to fully guarded single tree plots in a randomized block design experiment with five replications: 1) an untreated control; 2) a standard chemical thinning treatment of 75 $\mathrm{mg} \cdot \mathrm{L}^{-1} 6$-BA plus $600 \mathrm{mg} \cdot \mathrm{L}^{-1}$ carbaryl; 3) 75 $\mathrm{mg} \cdot \mathrm{L}^{-1} 6-\mathrm{BA}$; 4) $25 \mathrm{mg} \cdot \mathrm{L}^{-1}(+)-8^{\prime}$-acetylene ABA; 5) $25 \mathrm{mg} \cdot \mathrm{L}^{-1}(+)-8^{\prime}$-acetylene $\mathrm{ABA}$ plus $75 \mathrm{mg} \cdot \mathrm{L}^{-1} 6-\mathrm{BA}$; 6) $250 \mathrm{mg} \cdot \mathrm{L}^{-1} \mathrm{ABA}$; and 7) $250 \mathrm{mg} \cdot \mathrm{L}^{-1} \mathrm{ABA}$ plus $75 \mathrm{mg} \cdot \mathrm{L}^{-1}$ 6-BA. The treatments were applied with an airblast sprayer calibrated to deliver 1324 $\mathrm{L} \cdot \mathrm{ha}^{-1}$ to fully guarded single tree plots when the mean diameter of spur fruit was $11.1 \mathrm{~mm}$. A non-ionic organosilicone surfactant was included with Treatments 4 and 6 at $0.05 \%$ (Break Thru; Plant Health Technologies, Lathrop, CA). No additional surfactants were included with the other thinning treatments because they included a commercial formulation of 6-BA that has been formulated with a surfactant. Fruit set was measured as in the previous experiments. Total number and weight of fruit per tree were recorded at harvest. $g_{\mathrm{S}}$ was measured on six leaves per tree at 1- to 2-d intervals on the untreated control (Treatment 1), $25 \mathrm{mg} \cdot \mathrm{L}^{-1}(+)-8^{\prime}$-acetylene ABA (Treatment 4), and $250 \mathrm{mg} \cdot \mathrm{L}^{-1} \mathrm{ABA}$ (Treatment 6 ). $g_{\mathrm{S}}$ was measured with a steadystate diffusion porometer (Model SC-1; Decagon Devices, Pullman, WA). The youngest fully expanded leaves on vegetative shoots were chosen for conductance measurements. Total fruit number and weight per tree were recorded at harvest and mean fruit weight

Table 2. Effects of 6-benzyladenine (6-BA) combined with either S-abscisic acid (ABA) or (+)-8' -acetylene ABA on fruit set, yield, fruit number per tree, and mean fruit weight of 'Pink Lady'⿳⺈'/M.7 apple trees.

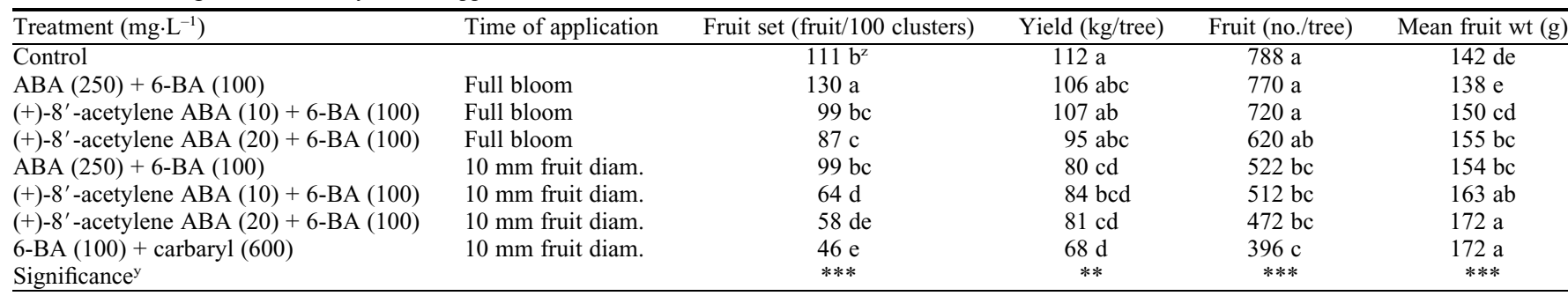

${ }^{2}$ Means within a column followed by different letters are significantly different at $P \leq 0.05$ as determined by Duncan's multiple range test ( $\mathrm{n}=5$ ).

y**, *** Significant at $P<0.01$ or 0.001 , respectively. 
Table 3. Effects of 6-benzyladenine (6-BA) combined with either S-abscisic acid (ABA) or (+)- $8^{\prime}$-acetylene ABA on fruit set, yield, fruit number per tree, and mean fruit weight of 'Morganspur Delicious'/MM.111 apple trees. ${ }^{z}$

\begin{tabular}{|c|c|c|c|c|}
\hline Treatment $\left(\mathrm{mg} \cdot \mathrm{L}^{-1}\right)$ & Fruit set (fruit/100 clusters) & Yield (kg/tree) & Fruit (no./tree) & Mean fruit wt $(\mathrm{g})$ \\
\hline 6-BA (75) & $78 \mathrm{a}$ & $61 \mathrm{a}$ & 321 a & $191 \mathrm{c}$ \\
\hline $\mathrm{ABA}(250)$ & $70 \mathrm{abc}$ & $62 \mathrm{a}$ & $305 \mathrm{a}$ & $204 \mathrm{bc}$ \\
\hline$(+)-8^{\prime}$-acetylene ABA (25) & $59 \mathrm{bc}$ & $58 \mathrm{a}$ & $251 \mathrm{a}$ & $238 \mathrm{abc}$ \\
\hline$(+)-8^{\prime}$-acetylene ABA $(25)+6$-BA $(75)$ & $57 \mathrm{c}$ & $55 \mathrm{a}$ & $255 \mathrm{a}$ & $219 a b c$ \\
\hline 6-BA (75) + carbaryl (600) & $19 \mathrm{~d}$ & $19 \mathrm{~b}$ & $81 \mathrm{~b}$ & $260 \mathrm{a}$ \\
\hline Significance $^{\mathrm{x}}$ & $* * *$ & $* * *$ & $* * *$ & * \\
\hline
\end{tabular}

${ }^{2}$ Treatments were applied when the mean fruit diameter was $11.1 \mathrm{~mm}$.

${ }^{\mathrm{y}}$ Means within a column followed by different letters are significantly different at $P<0.05$ as determined by Duncan's multiple range test (n $=5$ ).

x*, *** Significant at $P<0.05$ or 0.001 , respectively.
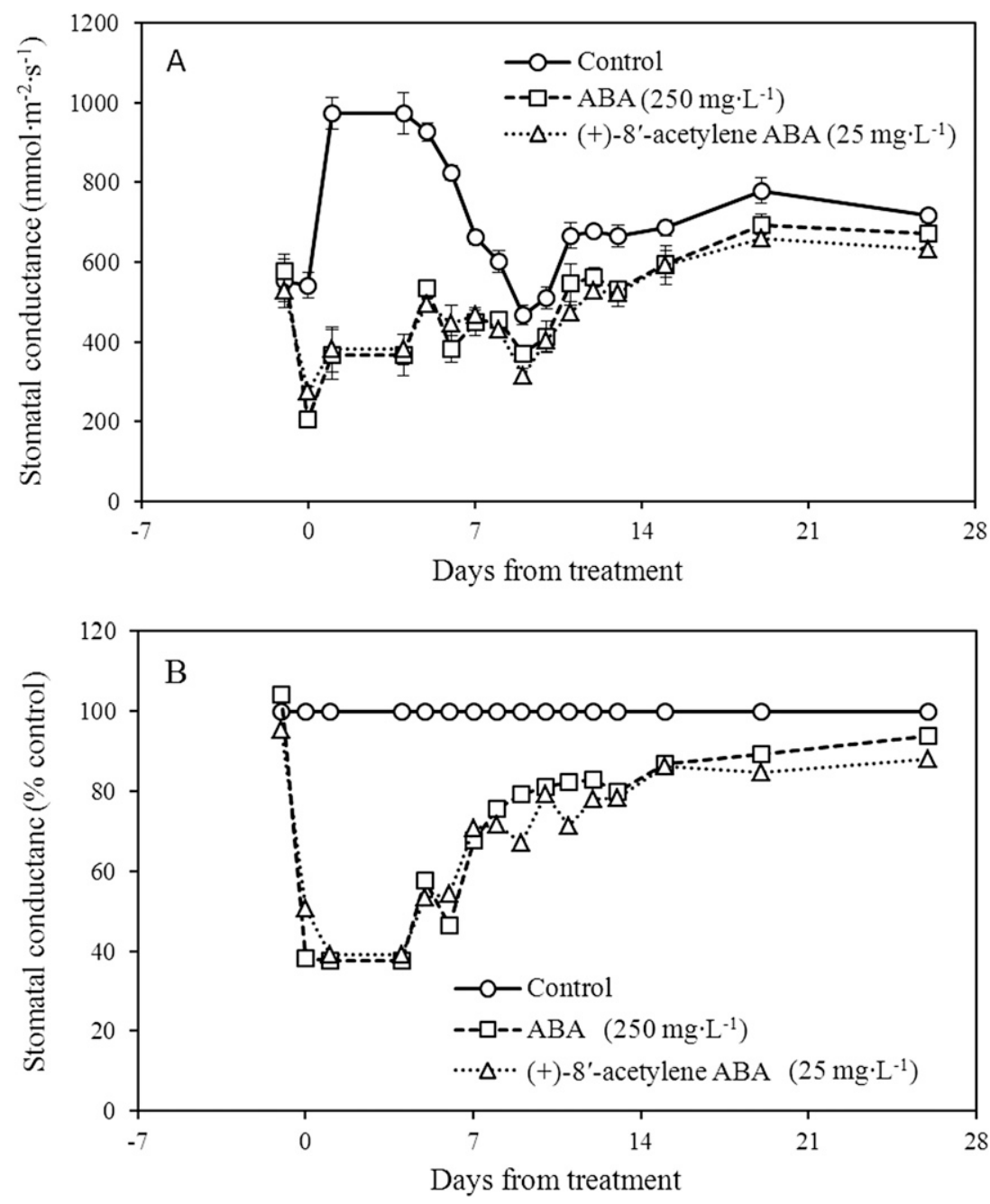

Fig. 2. Effect of $250 \mathrm{mg} \cdot \mathrm{L}^{-1} \mathrm{~S}$-abscisic acid (ABA) or $25 \mathrm{mg} \cdot \mathrm{L}^{-1}(+)-8^{\prime}$-acetylene ABA on stomatal conductance $\left(g_{\mathrm{S}}\right)$ of 'Morganspur Delicious'/MM.111 apple trees. Initial measurements were taken $1 \mathrm{~d}$ before treatment and measurements on Day 0 were taken $3 \mathrm{~h}$ after treatments were applied. Absolute values of $g_{\mathrm{S}}$ are presented in $\mathbf{A} ; g_{\mathrm{S}}$ relative to the control value on each day is presented in $\mathbf{B}$. Data points in $\mathbf{A}$ represent means $\pm \mathrm{SE}(\mathrm{n}=5)$.

calculated from these data. In addition, the number of fully developed seeds and seed traces was counted in a random sample of 10 fruit per tree. The proportion of parthenocarpic fruit was calculated from this data. Fruit shape (length:diameter ratio) was measured on this sample.

'Imperial Gala'/M.7-2013. Ten uniform vegetative shoots were selected on each of five replicate 'Imperial Gala'/M.7 trees. One shoot on each tree was sprayed with (+)- $8^{\prime}$-acetylene ABA at $0,2.5,10,25$, or $50 \mathrm{mg} \cdot \mathrm{L}^{-1}$ or with $\mathrm{ABA}$ at $0,25,100,250$, or $500 \mathrm{mg} \cdot \mathrm{L}^{-1}$. A nonionic organosilicone surfactant (Break Thru) was included with all of the treatments at $0.05 \%$. Stomatal conductance was measured $1 \mathrm{~d}$ after treatment on five fully expanded leaves per shoot as previously described. The number of leaves that abscised on each shoot was counted weekly until $21 \mathrm{~d}$ after treatment.
Statistical analysis. The data were analyzed using analysis of variance procedures in SAS software (Version 9.2; SAS Institute Inc., Cary, NC). Treatment effects on fruit set, total yield, fruit number, and mean fruit weight were analyzed using the generalized linear model procedure and means separation by LSMEANS. Differences between treatment means were assessed by Duncan's multiple range test at the $0.05 P$ level.

\section{Results}

All of the treatments reduced fruit set compared with the control in the 2010 'Imperial Gala'/M.7 study (Table 1). The most aggressive thinning treatments were the commercial standard (6-BA plus carbaryl) and the combination of 6-BA plus NAA. Combinations of $\mathrm{ABA}$ and 6-BA reduced fruit set; however, there was no clear effect of ABA concentration. NAA plus $500 \mathrm{mg} \cdot \mathrm{L}^{-1} \mathrm{ABA}$ reduced fruit set compared with the control. The thinning activity of this combination was significantly less than the combination of NAA and 6-BA. Taken together, these results indicate that although combinations of ABA with either 6-BA or NAA exhibited thinning activity, the level of thinning was significantly reduced compared with combinations of current commercially available thinning chemicals: 6-BA and carbaryl or 6-BA and NAA. Differences in yield and fruit number per tree and mean fruit weight of 'Imperial Gala'/M.7 at harvest appeared related to treatment effects on fruit set and cropload.

The combination of $20 \mathrm{mg} \cdot \mathrm{L}^{-1}(+)-8^{\prime}-$ acetylene ABA plus 6-BA was the only bloomthinning treatment to reduce fruit set of 'Pink Lady $^{\mathrm{TM}}$ '/M.7 compared with the untreated control. All thinning treatments applied at the $10-\mathrm{mm}$ fruit diameter stage exhibited some degree of thinning compared with the control (Table 2). The combination of $20 \mathrm{mg} \cdot \mathrm{L}^{-1}$ $(+)-8^{\prime}$-acetylene ABA plus 6-BA reduced fruit more effectively than $250 \mathrm{mg} \cdot \mathrm{L}^{-1}$ ABA plus 6 -BA, indicating the thinning activity of $(+)-8^{\prime}-$ acetylene $\mathrm{ABA}$ was $\approx 10$-fold higher than ABA. Like in the previous study, differences in yield and fruit number per tree, and mean fruit weight of 'Pink Lady' ${ }^{\mathrm{TM}}$ '/M.7 at harvest, appeared related to treatment effects on fruit set and cropload.

Thinning treatments that included 25 $\mathrm{mg} \cdot \mathrm{L}^{-1}(+)-8^{\prime}$-acetylene ABA reduced fruit set of 'Morganspur Delicious'/MM.111 in 

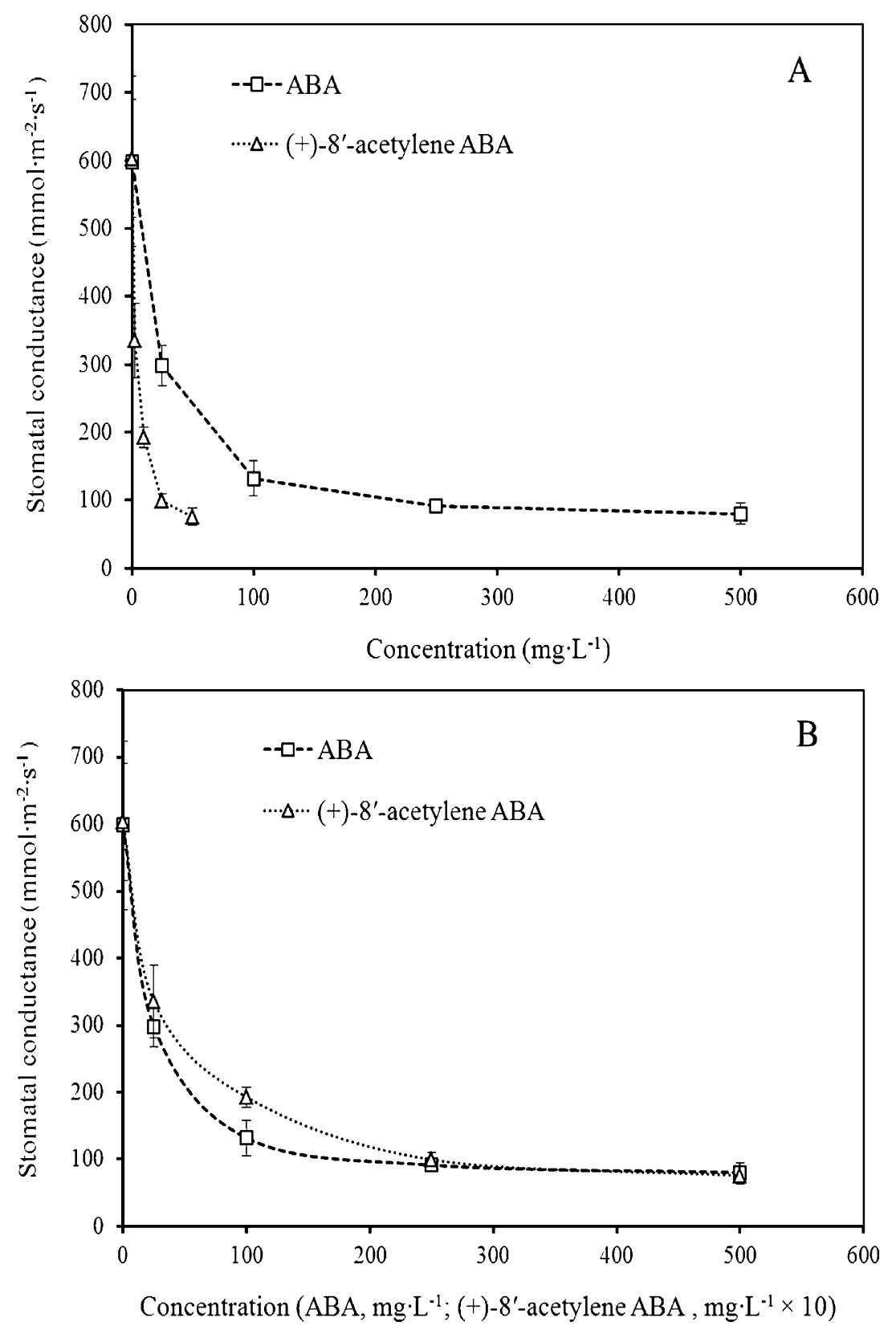

Fig. 3. Comparison of effect of S-abscisic acid (ABA) and (+)-8'-acetylene ABA concentration on stomatal conductance of 'Imperial Gala'/M.7 apple trees. Conductance values are plotted using a common scale for ABA and (+)- $8^{\prime}$-acetylene ABA in $\mathbf{A}$; the same data are presented in $\mathbf{B}$ except conductance values for $(+)-8^{\prime}$-acetylene ABA concentration are multiplied by a factor of 10 . Stomatal conductance was measured $1 \mathrm{~d}$ after treatment. Data points represent means $\pm \operatorname{SE}(\mathrm{n}=5)$.

2013, whereas treatments that included 250 $\mathrm{mg} \cdot \mathrm{L}^{-1} \mathrm{ABA}$ were without effect on fruit set (Table 3). The standard thinning treatment of $75 \mathrm{mg} \cdot \mathrm{L}^{-1}$ 6-BA plus $600 \mathrm{mg} \cdot \mathrm{L}^{-1}$ carbaryl overthinned 'Morganspur Delicious'/MM.111, reducing fruit set to 19 fruit per 100 clusters compared with 78 fruit per 100 clusters for the control. This overthinning was also reflected by a similar reduction in yield and fruit number per tree and increased mean fruit weight at harvest. Unlike the previous experiments, trees in the 2013 'Morganspur Delicious'/MM.111 study were hand-thinned to a commercial cropload at the completion of natural fruit drop. For this reason, there were no effects of $(+)-8^{\prime}$-acetylene ABA on tree yield, fruit number, and mean fruit weight at harvest. reduction in $g_{\mathrm{S}} 1 \mathrm{~d}$ after treatment resulted from application of ABA and (+)- $8^{\prime}$-acetylene $\mathrm{ABA}$ at $25 \mathrm{mg} \cdot \mathrm{L}^{-1}$ and $2.5 \mathrm{mg} \cdot \mathrm{L}^{-1}$, respectively. Some leaf abscission was observed after application of $500 \mathrm{mg} \cdot \mathrm{L}^{-1} \mathrm{ABA}$ and 50 $\mathrm{mg} \cdot \mathrm{L}^{-1}(+)-8^{\prime}$-acetylene ABA (Table 4). In the case of ABA, little additional leaf abscission was observed $7 \mathrm{~d}$ after treatment, whereas leaves continued to abscise for $21 \mathrm{~d}$ after application of $(+)-8^{\prime}$-acetylene ABA. Concentrations of $\mathrm{ABA}$ and $(+)-8^{\prime}$-acetylene $\mathrm{ABA}$ that exhibited thinning activity $\left(250 \mathrm{mg} \cdot \mathrm{L}^{-1}\right.$ and $25 \mathrm{mg} \cdot \mathrm{L}^{-1}$, respectively) did not result in increased leaf abscission compared with the control. Furthermore, no leaf abscission was observed in any of the thinning studies reported here.

There were no effects of $\mathrm{ABA}$ or $(+)-8^{\prime}-$ acetylene $\mathrm{ABA}$ on fruit shape of 'Morganspur Delicious'/MM.111 as measured by the length:diameter ratio; however, some treatments did reduce seed number per fruit and the proportion of parthenocarpic fruit at harvest (Table 5). When either 6-BA or $(+)-8^{\prime}$-acetylene ABA was applied individually, they did not influence seed development; however, when they were applied in combination, the number of fully developed seeds per fruit was decreased and the number of parthenocarpic fruit at harvest was increased to $24 \%$ compared with only $2 \%$ in the control (Table 5). In comparison, application of ABA alone or in combination with 6-BA was without effect on seed development. Application of the commercial chemical thinning standard of 6-BA + carbaryl reduced the number of fully developed seeds per fruit and the proportion of parthenocarpic fruit at harvest more severely than the combination of 6-BA and (+)- 8 ' -acetylene ABA (Table 5).

\section{Discussion}

Results from these experiments support previous findings that ABA can trigger abscission in young apple fruit (Edgerton, 1971; Greene et al., 2011). At the concentrations used in the present studies, ABA would be considered a mild thinner compared with commercially available chemical thinning agents. The mode of action of ABA as a thinning agent is probably related to the creation of a transient reduction in the supply of carbohydrates to developing fruit resulting from a stomatal limitation of photosynthesis, although other mechanisms cannot be ruled out. ABA reduced $g_{\mathrm{S}}$ by $60 \%$ within $3 \mathrm{~h}$ of application, and conductance did not begin to recover until $4 \mathrm{~d}$ after application. Full recovery of $g_{\mathrm{S}}$ was gradual, taking $21 \mathrm{~d}$ or more in the case of 'Morganspur Delicious'/MM.111. Given the direct positive relationship between $g_{\mathrm{S}}$ and net assimilation in apple (Lakso, 1979; Massonnet et al., 2007), this suppression is likely to have significantly reduced the supply of carbohydrates to developing fruits.

The efficacy of ABA as a chemical thinning agent in apple will be dependent on whole-tree net carbon assimilation as determined by the combined effects of environmental conditions 
Table 4. Comparison of effects of S-abscisic acid (ABA) or (+)- $8^{\prime}$-acetylene ABA concentration on leaf abscission (\%) on vegetative shoots of 'Imperial Gala'/M.7 apple trees after treatment.

\begin{tabular}{lcccc}
\hline & & \multicolumn{3}{c}{ No. of abscised leaves at different intervals after treatment (\%) } \\
\cline { 2 - 5 } Treatment & Concn $\left(\mathrm{mg} \cdot \mathrm{L}^{-1}\right)$ & $7 \mathrm{~d}$ & $14 \mathrm{~d}$ & $21 \mathrm{~d}$ \\
\hline ABA & 0 & $0.0 \mathrm{a}^{\mathrm{z}}$ & $0.0 \mathrm{a}$ & $0.0 \mathrm{a}$ \\
& 25 & $0.0 \mathrm{a}$ & $0.0 \mathrm{a}$ & $0.0 \mathrm{a}$ \\
& 100 & $0.7 \mathrm{a}$ & $0.7 \mathrm{a}$ & $0.7 \mathrm{a}$ \\
& 250 & $5.7 \mathrm{a}$ & $5.7 \mathrm{a}$ & $5.7 \mathrm{a}$ \\
$(+)-8^{\prime}$-acetylene & 500 & $15.4 \mathrm{~b}$ & $16.1 \mathrm{~b}$ & $16.8 \mathrm{~b}$ \\
ABA & 0 & $0.0 \mathrm{a}$ & $0.0 \mathrm{a}$ & $0.0 \mathrm{a}$ \\
& 2.5 & $0.0 \mathrm{a}$ & $0.7 \mathrm{a}$ & $0.7 \mathrm{a}$ \\
& 10 & $0.0 \mathrm{a}$ & $0.0 \mathrm{a}$ & $0.6 \mathrm{a}$ \\
& 25 & $6.5 \mathrm{a}$ & $7.3 \mathrm{a}$ & $10.5 \mathrm{ab}$ \\
Significance $^{\mathrm{y}}$ & 50 & $23.3 \mathrm{c}$ & $27.1 \mathrm{c}$ & $32.3 \mathrm{c}$ \\
\hline
\end{tabular}

${ }^{\mathrm{z}}$ Means within a column followed by different letters are significantly different at $P<0.05$ as determined by Duncan's multiple range test $(\mathrm{n}=5)$.

y*** Significant at $P<0.001$.

Table 5. Effects of 6-benzyladenine (6-BA) combined with either S-abscisic acid (ABA) or (+)- $8^{\prime}-$ acetylene $\mathrm{ABA}$ on seed development, parthenocarpy, and fruit length:diameter (L:D) ratio of 'Morganspur Delicious'/M.111 apple trees. ${ }^{\mathrm{z}}$

\begin{tabular}{lccccc}
\hline & \multicolumn{3}{c}{ Seeds/fruit (no.) } & Parthenocarpic & \\
\cline { 2 - 4 } Treatment (mg. $\left.\mathrm{L}^{-1}\right)$ & Full seeds & Trace seeds & Total seeds & fruit (\%) & Fruit L:D ratio \\
\hline Control & $7.8 \mathrm{a}^{y}$ & $0.8 \mathrm{ab}$ & $8.7 \mathrm{ab}$ & $2 \mathrm{a}$ & 0.94 \\
6-BA (75) & $8.3 \mathrm{a}$ & $0.9 \mathrm{ab}$ & $9.2 \mathrm{a}$ & $4 \mathrm{a}$ & 0.96 \\
ABA (250) & $7.4 \mathrm{a}$ & $0.7 \mathrm{ab}$ & $8.1 \mathrm{bc}$ & $2 \mathrm{a}$ & 0.95 \\
$(+)-8^{\prime}$-acetylene ABA (25) & $8.7 \mathrm{a}$ & $0.4 \mathrm{a}$ & $9.0 \mathrm{a}$ & $0 \mathrm{a}$ & 0.92 \\
ABA (250) + 6-BA (75) & $7.4 \mathrm{a}$ & $1.1 \mathrm{ab}$ & $8.5 \mathrm{ab}$ & $4 \mathrm{a}$ & 0.96 \\
$(+)-8^{\prime}$-acetylene ABA & $5.8 \mathrm{~b}$ & $1.7 \mathrm{~b}$ & $7.4 \mathrm{c}$ & $24 \mathrm{~b}$ & 0.96 \\
$(25)+6-B A(75)$ & & & & & \\
6-BA (75) + carbaryl (600) & $3.6 \mathrm{c}$ & $2.9 \mathrm{c}$ & $6.5 \mathrm{~d}$ & $40 \mathrm{c}$ & 0.91 \\
Significance & $* * *$ & $* * *$ & $* * *$ & $* * *$ & NS \\
\hline
\end{tabular}

${ }^{2}$ Treatments were applied when the mean fruit diameter was $11.1 \mathrm{~mm}$.

${ }^{y}$ Means within a column followed by different letters are significantly different at $P \leq 0.05$ as determined by Duncan's multiple range test $(\mathrm{n}=5)$.

${ }^{\mathrm{N} S}$, *** Nonsignificant or significant at $P<0.001$, respectively.

immediately after treatment and the extent and duration of a stomatal limitation of photosynthesis. For example, the thinning response is predicted to be much greater if cloudy days (reduced photosynthesis) and warm nights (high respiration) follow ABA application compared with sunny days (high photosynthesis) and cool nights (low respiration). In this regard, the efficacy of ABA as a chemical thinning agent may eventually be predicted using a carbon balance modeling approach (Lakso, 2011; Robinson and Lakso, 2011). However, such a strategy will require more complete description of the effects of ABA on whole-tree carbon acquisition rather than indirect $\left(g_{\mathrm{S}}\right)$ or direct (photosynthesis) measurements at an individual leaf level. Furthermore, if rates of ABA catabolism differ between apple cultivars, then the response to ABA may be cultivar-specific, making accurate prediction of the thinning response more difficult in a practical sense.

The ABA analog $(+)-8^{\prime}$-acetylene ABA exhibited thinning activity at rates that were one-tenth that of ABA. Direct comparison of the $g_{\mathrm{S}}$ response to varying rates of $\mathrm{ABA}$ and $(+)-8$-acetylene ABA provides clear evidence for the 10 -fold increase in biological activity of $(+)-8^{\prime}$-acetylene ABA compared with ABA. $(+)-8^{\prime}$-acetylene ABA is perceived as ABA-like by the receptor complex (Abrams et al., 2011) and is more persistent than ABA itself as a result of lower rates of catabolism (Cutler et al., 2000). (+)- 8 '-acetylene ABA was also shown to hyperinduce many ABAregulated genes, including the transcription factor MYBR1 suggested to be a negative regulator of $\mathrm{ABA}$ signal transduction (Huang et al., 2007). The incidence of parthenocarpic fruit at harvest was unaffected by ABA but was significantly increased by the combination of $(+)-8^{\prime}$-acetylene ABA and 6-BA. Interestingly, the incidence of parthenocarpic fruit was even higher in fruit treated with a standard chemical thinning spray of 6-BA + carbaryl. The reason why $(+)-8^{\prime}$-acetylene $\mathrm{ABA}+6$-BA stimulated parthenocarpic fruit development is unknown at this time. Because a relationship among seed number, fruit calcium content, and storage disorders is occasionally reported in apple (Bramlage et al., 1990), parthenocarpic fruit resulting from $(+)-8$-acetylene ABA +6 -BA treatment may have a higher risk of postharvest disorder development.

The thinning activity of $\mathrm{ABA}$ or $(+)-8$-acetylene ABA in the present studies was significantly lower than currently available thinning agents. Commercially acceptable levels of thinning after ABA or $(+)-8$-acetylene ABA application would require concentrations that could trigger unacceptable levels of leaf yellowing and/or abscission, although it has been suggested that inclusion of 6-BA can reduce ABA-related plant leaf yellowing (Greene et al., 2011; Liu et al., 2010). The leaf abscission we observed in the current study will probably limit the commercial potential for $\mathrm{ABA}$ or $(+)-8^{\prime}$-acetylene $\mathrm{ABA}$ alone as a chemical thinning agent in apple. The inhibitory effects of ABA or (+)- 8 '-acetylene $\mathrm{ABA}$ on $g_{\mathrm{S}}$ at concentrations lower than 250 $\mathrm{mg} \cdot \mathrm{L}^{-1}$ and $25 \mathrm{mg} \cdot \mathrm{L}^{-1}$, respectively, are likely to reduce the supply of carbohydrates to developing fruit. Carbon deficits within the tree at this time are believed to increase the sensitivity of developing fruit to chemical thinners. Thus, although ABA or (+)- $8^{\prime}$-acetylene ABA might not exhibit direct chemical thinning activity, their application could potentially increase the thinning activity of commercially available thinning agents. Such a strategy might be useful in situations where the fruit are otherwise insensitive to chemical thinners; for example, when environmental conditions favor a positive carbon balance within the tree. Alternatively, creation of a transient carbohydrate stress by ABA or $(+)-8$-acetylene ABA may permit equivalent thinning with reduced rates of currently available chemical thinning agents.

\section{Literature Cited}

Abrams, S., C. Benson, M. Loewen, J. Boyd, K Nelson, M. Kepka, and E. Grill. 2011. Probing abscisic acid receptor complexes with metabolites and structural analogs. Proc. $38^{\text {th }}$ Annu. Mtg. Plant Growth Regulat. Soc. Amer. p. $12-13$.

Anon. 2013. Integrated orchard management guide for commercial apples in the southeast. $16 \mathrm{Dec}$ 2013. <http://www.ces.ncsu.edu/fletcher/programs/apple/2013\%20Orchard $\% 20 \mathrm{Mgt} \% 20$ Guide.pdf $>$.

Balsevich, J.J., A.J. Cutler, N. Lamb, L.J. Friesen, E.U. Kurz, M.R. Perras, and S.R. Abrams. 1994. Response of cultured maize cells to $(+)$-abscisic acid, (-)-abscisic acid, and their metabolites. Plant Physiol. 106:135-142.

Basak, A. 2011. Efficiency of fruitlet thinning in apple 'Gala Must' by use of metamitron and artificial shading. J. Fruit and Ornamental Plant Res. 19:51-62.

Bepete, M. and A.N. Lakso. 1998. Differential effects of shade on early season fruit and shoot growth rates in 'Empire' apple branches. HortScience 33:823-825.

Bramlage, W.J., S.A. Weis, and D.W. Greene 1990. Observations on the relationships among seed number, fruit calcium, and senescent breakdown in apples. HortScience 25:351-353.

Byers, R.E., J.A. Barden, R.F. Polomski, R.W Young, and D.H. Carbaugh. 1990. Apple fruit abscission by photosynthetic inhibition. J. Amer. Soc. Hort. Sci. 115:14-19.

Byers, R.E., D.H. Carbaugh, C.N. Presley, and T.K. Wolf. 1991. The influence of low light on apple fruit abscission. J. Hort. Sci. 66:7-17.

Byers, R.E., C.G. Lyons, and K.S. Yoder. 1985. Peach and apple thinning by shading and photosynthetic inhibition. J. Hort. Sci. 60: 465-472.

Clever, M. 2007. A comparison of different thinning products applied to the apple variety 'Elstar Elshof' in the lower Elbe region. Erwerbs-Obstbau 49:107-109.

Cutler, A.J., P.A. Rose, T.M. Squires, M.K. Loewen, A.C. Shaw, J.W. Quail, J.E. Krochko, and S.R. Abrams. 2000. Inhibitors of abscisic acid 8'hydroxylase. Biochem. 39:13614-13624. 
Deckers, T., H. Schoofs, and W. Verjans. 2010. Looking for solutions for chemical fruit thinning on apple. Acta Hort. 884:237-244.

Dorigoni, A. and P. Lexxer. 2007. Chemical thinning of apple with new compounds. ErwerbsObstbau 49:93-96.

Edgerton, L.J. 1971. Apple abscission. HortScience 6:378-382.

Greene, D.W., J.R. Schupp, and H.W. Winzler. 2011. Effects of abscisic acid and benzyladenine on fruit set and fruit quality of apples. HortScience 46:604-609.

Greene, D.W. 2012. Influence of abscisic acid and benzyladenine on fruit set and fruit quality of 'Bartlett' pears. HortScience 47:1607-1611.

Huang, D., M.R. Jaradat, W. Wu, S.J. Ambrose, A.R. Ross, S.R. Abrams, and A.J. Cutler. 2007. Structural analogs of ABA reveal novel features of ABA perception and signaling in Arabidposis. Plant J. 50:414-428.

Kondo, S., S. Sugaya, S. Sugawa, M. Ninomiya, M. Kittikorn, K. Okawa, H. Ohara, K. Ueno, Y. Todoroki, M. Mizutani, and N. Hirai. 2012. Dehydration tolerance in apple seedlings is affected by an inhibitor of ABA $8^{\prime}$-hydroxylase CYP707A. J. Plant Physiol. 169:234-241.

Krochko, J.E., G.D. Abrams, M.K. Loewen, S.R. Abrams, and A.J. Cutler. 1998. (+)-Abscisic acid $8^{\prime}$-hydroxylase is a cytochrome $\mathrm{P} 450$ monoxygenase. Plant Physiol. 118:849-850.

Lafer, G. 2010. Effects of chemical thinning with metamitron on fruit set, yield and fruit quality of 'Elstar' Acta Hort. 884:531-536.

Lakso, A.N. 1979. Seasonal changes in stomatal response to leaf water potential in apple. J. Amer. Soc. Hort. Sci. 104:58-60.

Lakso, A.N. 2011. Early fruit growth and drop-The role of carbon balance in the apple tree. Acta Hort. 903:733-742.

Liu, X., D.D. Woolard, and P. Petracek. 2010. Use of plant growth regulators to reduce abscisic acid related plant leaf yellowing. U.S. Patent Application 20100022562 A1.

Massonnet, C., E. Costes, S. Rambal, E. Dreyer, and J.L. Regnard. 2007. Stomatal regulation of photosynthesis in apple leaves: Evidence for different water use strategies between two cultivars. Ann. Bot. (Lond.) 100:1347-1356.

McArtney, S., M. White, I. Latter, and J. Campbell. 2004. Individual and combined effects of shading and thinning chemicals on abscission and dry-matter accumulation of 'Royal Gala' apple fruit. J. Hort. Sci. Biotechnol. 79:441-448.

McArtney, S.J. and J.D. Obermiller. 2012a. Comparison of the effects of metamitron on chlorophyll fluorescence and fruit set in apple and peach. HortScience 47:509-514.
McArtney, S.J. and J.D. Obermiller. 2012b. Use of 1 -aminocyclopropane carboxylic acid and metamitron for delayed thinning of apple fruit. HortScience 47:1612-1616.

Robinson, T.L. and A.N. Lakso. 2011. Predicting chemical thinner response with a carbohydrate model. Acta Hort. 903:743-750.

Rose, P.A., A.J. Cutler, N.M. Irvine, A.C. Shaw, T.M. Squires, M.K. Loewen, and S.R. Abrams. 1997. $8^{\prime}$-Acetylene ABA: An irreversible inhibitor of ABA 8' -hydroxylase. Bioorg. Med. Chem. Lett. 7:2543-2546.

Todoroki, Y., K. Kobayashi, M. Shirakura, H. Aoyama, K. Takatori, H. Nimitkeatkai, M. Jin, S. Hiramatsu, K. Ueno, S. Kondo, M. Mizutani, and N. Hirai. 2009. Abscinazole-F1, a conformationally restricted analogue of the plant growth retardant uniconazole and an inhibitor of $\mathrm{ABA}$ 8 '-hydroxylase CYP707A with no growthretardant effect. Bioorg. Med. Chem. 17:6620 6630 .

Zibordi, M., S. Domingos, and L. Corelli Grappadelli. 2009. Thinning apples via shading: An appraisal under field conditions. J. Hort. Sci. Biotechnol. ISAFRUIT Spec. Issue:138144.

Zucconi, F.R., R. Stosser, and M.J. Bukovac. 1969. Promotion of fruit abscission with abscisic acid. Bioscience 19:815-817. 